\title{
Primary Diffuse Large B-Cell Lymphoma of the Mandible: Case Report and Review of the Literature
}

\author{
Amr Bugshan $^{\mathrm{a}} \quad$ James Kassolis $^{\mathrm{b}} \quad$ John Basile $^{\mathrm{a}}$ \\ ${ }^{a}$ Department of Oncology and Diagnostic Sciences, Dental School, University of Maryland, \\ Baltimore, Md., and ${ }^{b}$ Towson Periodontal Associates, Towson, Md., USA
}

\section{Key Words}

Mandible · Non-Hodgkin's lymphoma · Periapical lesion · Oral cancer · Oral cavity · Swelling

\begin{abstract}
In the oral cavity, extranodal non-Hodgkin's lymphoma can occur in the periapical region either in the maxilla or mandible. Also, it can mimic inflammatory lesions that arise around the teeth apices such as periapical granuloma, radicular cyst and osteomyelitis. Misdiagnosis of lymphomas in the jaws may reduce the chance of successful treatment and worsen the prognosis. Therefore, any growth of periapical tissue must be submitted for histopathological evaluation to avoid a delay in the diagnosis. We present a case of extranodal non-Hodgkin's lymphoma of a 53-year-old male in the right posterior mandible that was initially misdiagnosed as a reactive periapical lesion. This case illustrates the importance for both the pathologist and the clinician of considering malignant lesions such as lymphoma in the differential diagnosis of periapical radiolucency.

(C) 2015 The Author(s)

Published by S. Karger AG, Basel
\end{abstract}

\section{Introduction}

Although extranodal non-Hodgkin's lymphoma (NHL) in the oral cavity is considered to be relatively rare, lymphomas, a cancer of lymphoid tissue (either B- or T-lymphocyte) are the second most common malignant tumor in the head and neck after squamous cell carcinoma [1, 2]. Hodgkin's lymphoma (HL) and NHL are the two main classifications of lymphomas, with the latter being the most common according to the most recent American Cancer Society update [3]. The difference between the two types can only be recognized under the microscope $[1,3]$. Reed-Sternberg cells, the binucleated or multinucleated giant cells charac- 
Bugshan et al:: Primary Diffuse Large B-Cell Lymphoma of the Mandible: Case Report and Review of the Literature

teristic of HL, are essential for the diagnosis of HL [3]. NHL accounts for about 4\% of all cancers in the USA. The estimate of new cases of NHL in 2015 is 71,850 people $(39,850$ males and 32,000 females). On the other hand, only 9,050 new cases $(3,950$ females and 5,100 males) of HL are estimated to occur this year [4]. NHL commonly arises in the lymph node, but extranodal involvement can occur [1]. A retrospective study by Urquhart and Berg [5] on 311 patients diagnosed with nodal and extranodal lymphoma in the head and neck found that about $23 \%$ of extranodal lymphomas were NHL, while only $4 \%$ were HL. Lymphomas in the oral cavity are usually extranodal and are found either in soft tissue or centrally in bone [1]. The most common intraoral location is the gingiva followed by the palate, while the most frequent locations in the head and neck are the tonsils followed by the parotid gland [6].

\section{Case Report}

A 54-year-old male presented with a history of root canal treatment to tooth No. 30, followed by periapical surgery. At the time of periapical surgery, a periodontal problem was noted on tooth No. 32. Two weeks after the surgery, the patient presented with right posterior swelling that distorted the right cheek. He stated that his lower lip was 'numb'. On intraoral examination, a large gingival swelling associated with tooth No. 32 was noticed, which had a clinical appearance of a pyogenic granuloma. There was a class III mobility to tooth No. 32. The swelling appeared to progress mesially on the edentulous ridge distal to tooth No. 30. The buccal mucosal tissue and gingiva was firm extending to the bicuspid and the vestibule. Tooth No. 32 was extracted, and the associated gingival lesion was removed. During the extraction, a large area of necrotic bone in the socket of tooth No. 32 and on the ridge near tooth No. 31 was observed. The lesion also progressed to the apex of the distal root of tooth No. 30. The radiographic findings were that of a radiolucent destruction of bone with ill-defined margins around tooth No. 30 that extended posteriorly to tooth No. 32 (fig. 1). The differential diagnosis based on clinical and radiographic finding was an acute abscess, acute osteomyelitis or a malignant tumor such as an osteosarcoma. The patient's medical history was significant for hypertension and hepatitis.

Two tissue specimens were submitted. The first was during the apical surgery and the second was 2 weeks later when tooth No. 30 and No. 32 were extracted. The diagnosis for the first specimen was a periapical granuloma. The histopathology of the second specimen showed multiple fragments of a squamous mucosa, soft tissue and bone with a dense lymphoid infiltrate (fig. 2a). The lymphocytes were intermediate-to-large and atypical with a moderate amount of cytoplasm. The nuclei had finely clumped chromatin with variably prominent nucleoli, and there were abundant mitotic figures throughout the lesion (fig. 2b). A panel of immunostains was performed, with cells exhibiting positivity for CD20 (fig. 2c) and CD79a, weak positivity for CD10 (fig. 2d) and variable staining for Bcl-6 (fig. 2e). All cells were negative for CD34, TdT, Cyclin D1 and CD23. CD3 showed a scattered positivity for Tcells (fig. 2f). Interphase fluorescence in situ hybridization (FISH) showed no evidence of cMYC/IgH translocation. Based on the histopathology and immunohistochemical findings, the lesion was diagnosed as a high-grade B-cell lymphoma.

\section{Discussion}

Lymphomas represent 3.5\% of all intraoral malignancies [7]. After squamous cell carcinoma, lymphoma is the second most common neoplasm in the head and neck region [8]. Diffuse large 
Bugshan et al.: Primary Diffuse Large B-Cell Lymphoma of the Mandible: Case Report and Review of the Literature

B-cell lymphoma (DLBCL) is the most common subtype of NHL in the head and neck area [9]. A retrospective review stated that, out of 381 cases of head and neck NHL, 100 of which were extranodal, 16 patients $(16 \%)$ had jaw bone involvement, most of which were DLBCL. The mandible was the most common bone affected $[10,11]$. Unexplained tooth mobility, bone pain or discomfort, and radiographic changes can be observed in most of these cases. An incorrect diagnosis and subsequent delayed treatment can lead to bone expansion, cortical bone perforation and intraoral soft tissue mass formation. Radiographically, an ill-defined radiolucency with irregular margins can be detected in advanced cases [1]. DLBCL is the most common type of NHL in the United States [3]. The median age is 64 years, and men are slightly more affected than women $[3,12]$. The tumor is usually aggressive, growing rapidly and causing severe bone destruction [12].

Microscopically, DLBCLs consist of large tumor cells with large nuclei that are more than twice the size of lymphocytes. These tumor cells show either centroblastic or immunoblastic features. Centroblasts have round or irregular nuclei and membrane-bound nucleoli, while immunoblasts have round nuclei and centrally located prominent nucleoli. DLBCLs express BCL2 in about $50 \%$ of cases. Multiagent chemotherapy together with anti-CD20 (rituximab) is usually the treatment of choice for DLBCL [3].

The diagnosis of lymphoma in the jaws is difficult and often delayed for many reasons. For example, clinical and radiographic presentations are not specific for lymphoma. Clinically, lymphoma may cause vague pain and discomfort, which might be easily misdiagnosed as periapical lesion developed from an odontogenic infection. Radiographic changes in early stages of the tumor may be subtle and usually are only detected late in the disease as an illdefined radiolucency that might resemble a dental abscess. Histologically, NHLs are characterized by a proliferation of lymphocytic appearing cells easily mistaken for a periapical granuloma or cyst [1]. The clinician must be aware of the jaw tumor symptoms, which can help in early detection and treatment. Rapid local destruction of the bone without obvious odontogenic infection is a key characteristic of jaw tumors [12]. Persistent jaw pain and tooth mobility caused by rapid bone destruction may be an early indication of malignancy [13]. In advanced cases, swelling, pain, lip numbness and pathologic fracture are also associated with a primary bony lesion [12]. On the other hand, the pathologist must examine the tissue section carefully under the light microscope. Immunohistochemistry is very helpful to rule out NHL in suspicious periapical lesions. Therefore, clinicopathologic correlation is crucial to reach the correct diagnosis in clinically suspicious cases such as a malignant tumor in the jaw.

\section{Acknowledgements}

Special thanks to Dr. Kathleen H Burns, Department of Pathology, Johns Hopkins University School of Medicine, for the immunostains and the assistance provided.

\section{Statement of Ethics}

The submitted documents represent original research that has not been published previously either in whole or in part in any form, and is not currently submitted for publication elsewhere. All authors have read and approved the manuscript. 


\section{Case Reports in Oncology}

\begin{tabular}{l|l}
\hline Case Rep Oncol 2015;8:451-455 \\
\hline DOI: $10.1159 / 000441469$ & $\begin{array}{l}\text { C } 2015 \text { The Author(s). Published by S. Karger AG, Basel } \\
\text { www.karger.com/cro }\end{array}$ \\
\hline
\end{tabular}

Bugshan et al.: Primary Diffuse Large B-Cell Lymphoma of the Mandible: Case Report and Review of the Literature

\section{Disclosure Statement}

The authors report no conflicts of interest.

\section{References}

Neville BW: Oral and Maxillofacial Pathology, ed 3. St. Louis, Saunders/Elsevier, 2009.

-2 Rooney N, Ramsay AD: Lymphomas of the head and neck. 2; The B-cell lymphomas. Eur J Cancer B Oral Oncol 1994;30B:155-159.

3 Barnes L: Surgical Pathology of the Head and Neck, ed 3. New York, Informa Healthcare, 2009.

4 American Cancer Society: Cancer Facts and Figures 2015. Atlanta, American Cancer Society, 2015.

-5 Urquhart A, Berg R: Hodgkin's and non-Hodgkin's lymphoma of the head and neck. Laryngoscope 2001;111:1565-1569.

-6 Guevara-Canales JO, Morales-Vadillo R, de Faria PE, Sacsaquispe-Contreras SJ, Leite FP, Chaves MG: Systematic review of lymphoma in oral cavity and maxillofacial region. Acta Odontol Latinoam 2011;24:245-250.

7 Epstein JB, Epstein JD, Le ND, Gorsky M: Characteristics of oral and paraoral malignant lymphoma: a population-based review of 361 cases. Oral Surg Oral Med Oral Pathol Oral Radiol Endod 2001;92:519-525.

-8 Shindoh M, Takami T, Arisue M, Yamashita T, Saito T, Kohgo T, et al: Comparison between submucosal (extra-nodal) and nodal non-Hodgkin's lymphoma (NHL) in the oral and maxillofacial region. J Oral Pathol Med 1997;26:283-289.

\$9 Szumera-Cieckiewicz A, Galazka K, Szpor J, Rymkiewicz G, Jesionek-Kupnicka D, Gruchala A, et al: Distribution of lymphomas in Poland according to World Health Organization classification: analysis of 11,718 cases from National Histopathological Lymphoma Register project - the Polish Lymphoma Research Group study. Int J Clin Exp Pathol 2014;7:3280-3286.

$\checkmark 10$ Etemad-Moghadam S, Tirgary F, Keshavarz S, Alaeddini M: Head and neck non-Hodgkin's lymphoma: a 20year demographic study of 381 cases. Int J Oral Maxillofac Surg 2010;39:869-872.

-11 Djavanmardi L, Oprean N, Alantar A, Bousetta K, Princ G: Malignant non-Hodgkin's lymphoma (NHL) of the jaws: a review of 16 cases. J Craniomaxillofac Surg 2008;36:410-414.

12 Regezi JA, Sciubba JJ, Jordan RCK: Oral Pathology: Clinical Pathologic Correlations. St. Louis, Saunders/Elsevier, 2008.

13 Mercadante S: Malignant bone pain: pathophysiology and treatment. Pain 1997;69:1-18.
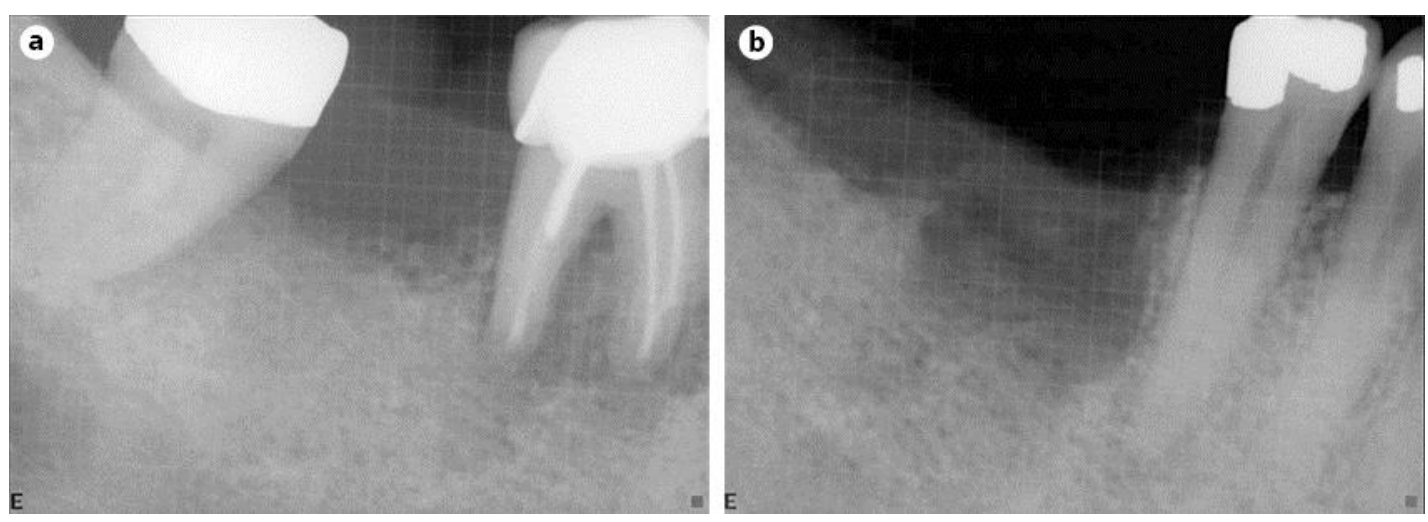

Fig. 1. Primary NHL of the mandible. a Periapical radiograph showing widening of the periodontal ligament and ill-defined radiolucency extending from tooth No. 30 to tooth No. 32. b Periapical radiograph showing bony destruction after extraction of teeth No. 30 and 32. 
Bugshan et al.: Primary Diffuse Large B-Cell Lymphoma of the Mandible: Case Report and Review of the Literature
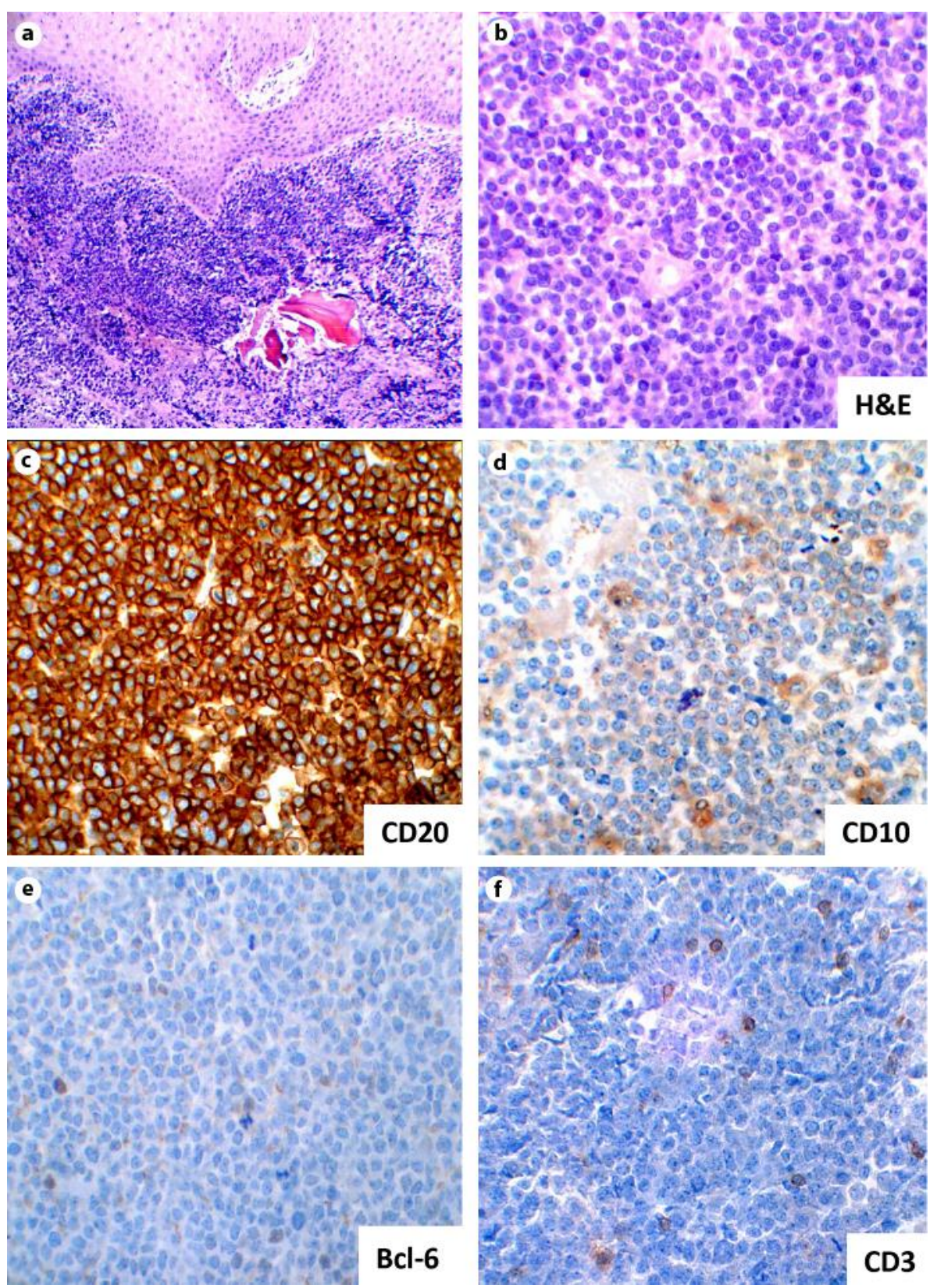

Fig. 2. Right posterior mandible biopsy. a Photomicrograph showing multiple fragments of a squamous mucosa, soft tissue and bone with a dense lymphoid infiltrate $(\times 10$ magnification). $\mathbf{b}$ Photomicrograph showing an aggregate of atypical lymphoid cells (H\&E staining; $\times 40$ magnification). c Photomicrograph of immunohistochemical stain showing sheets of large mononuclear lymphoid cells positive for CD20 $(\times 40$ magnification). $\mathbf{d}$ Immunostaining for a CD10 showing a weak positivity ( $\times 40$ magnification). $\mathbf{e}, \mathbf{f}$ Scattered positivity is showing for CD3 and Bcl- 6 immunostains ( $\times 40$ magnification). 